\title{
Water quality of urban water bodies - a threat for amphibians?
}

\author{
${ }^{*}$ Karolina A. Budzik, "*Krystian M. Budzik, ${ }^{* * *}$ Paulina Kukiełka, ${ }^{* * *}$ Anna Laptaś, ${ }^{*}$ Ewa E. Bres \\ *Department of Comparative Anatomy, Zoological Institute, Jagiellonian University, \\ Gronostajowa 9, 30-387 Kraków; Poland, e-mail: karolina.kawa@uj.edu.pl \\ **Department of Taxonomy, Phytogeography and Herbarium, Jagiellonian University, \\ Kopernika 27, 31-501 Kraków, Poland \\ ***Department of Environmental Chemistry, Faculty of Chemistry, Jagiellonian University, \\ Gronostajowa 3, 30-387 Kraków, Poland
}

\begin{abstract}
Most studies on the effects of water quality on amphibians concern experimental conditions. The main aim of our study was to determine whether the quality of water bodies in urban environment may be a factor leading to local extinction of some amphibian species. We investigated the current amphibian richness in Kraków water bodies and the water quality of these water bodies. We compared our results with available historical data on amphibian richness in Kraków and we determined the number of amphibian species local extinction for each water body. Then, we compared water bodies with low amphibian extinction rates to water bodies with high amphibian extinction rates in respect to ten water quality chemical indicators. We found that the values of most chemical indicators were higher in water bodies with high amphibian extinction rates. The values of magnesium and chloride ion concentration, as well as conductivity appeared to differ the most between these two types of water bodies which is connected mainly with spring run-off into the water bodies. The results of this study demonstrate that water pollution may lead to local extinction of amphibian species.
\end{abstract}

Keywords: water pollution, Kraków, road run-off, deicers.

\section{Introduction}

Urban development involves a number of environmental changes, including construction of new buildings, industrial plants and roads, which adversely affect the local wildlife. Various negative impacts of urban development include habitat loss or its fragmentation, formation of barriers to animal migration, enhancing isolation of populations and reduction of gene flow (Reh \& Seitz 1990; Gibbs 1998; St. Clair 2003; Andrews \& Gibbons 2005). Among vertebrates, amphibians appear to be especially vulnerable to such alternations (Stuart et al. 2004; Hof et al. 2011). Their migration need, water-dependent breeding, aquatic larval stages, as well as permeable skin and limited movements make amphibians particularly vulnerable to any changes in the environment (Stebbins \& Cohen 1995). Therefore, amphibians are considered good indicators of an ecosystem health (Vitt et al. 1990) and they are often used as model organisms for investigating the environmental effect of contamination with chemical factors (Loman \& Lardner 2006; Klaver et al. 2013).

There are many studies concerning the impact of water quality on amphibians. Some of them concern the natural environment (Loman \& Lardner 2006; Klaver et al. 2013), however the vast majority relate to experimental conditions (Dolmen 2006; Sanzo \& Hecnar 2006; Chambers 2011; Skei \& Harless et al. 2011). The studies usually focus on water quality indicators, which have a direct impact on amphibian survival (Dolmen 2006; Sanzo \& Hecnar 2006; Skei \& Harless et al. 2011), development and growth (Baker \& Waights 1993; Snodgrass et al. 2008), as well as behavior (Sanzo \& Hecnar 2006; Karraker et al. 2008; Chambers 2011). However, little is known about a multiannual effect of water quality on amphibian popu- 
lations in their natural environment, which requires longterm research. Therefore, given historical data on amphibian richness for Kraków, we studied if the quality of water can be a limiting factor for the occurrence of amphibians in an urban environment. Firstly, we investigated the current amphibian presence in Kraków water bodies and the water quality of these water bodies. Secondly, we compared current distribution with historical data and we determined the number of amphibian species extinction for each water body. Lastly, we compared water bodies with low and high amphibian extinction rates in respect to ten water quality variables. We hypothesized that the water bodies with high extinction rates should be characterized by higher values of harmful water quality indicators.

\section{Material and methods}

\subsection{Study area}

Field work was conducted within the administrative boundaries of Kraków, mainly in the central part of the city (Fig. 1). The study concerned 15 permanent water bodies. Four water bodies were situated in the vicinity of forests, meadows and fallow lands (within a radius of at least 300 $\mathrm{m}$ from the water body), while the remaining were located in an urban landscape with a mixture of meadows, parks, allotments and woodlots. More than half of the water bodies $(53 \%)$ were situated in the immediate vicinity of roads. The area of the water bodies ranged from 0.33 ha to 28.22 ha. In terms of area the water bodies could be divided into: 'small' - up to 0.2 ha (mean $=0.10$ ha, $\mathrm{SD}=0.07 \mathrm{ha}$ ), 'medium' - between 0.2 ha and 2.0 ha (mean $=0.63$ ha, $\mathrm{SD}=$ $0.54 \mathrm{ha}$ ) and 'large' - more than 2.0 ha (mean $=12.47$ ha, $\mathrm{SD}=13.87 \mathrm{ha}$ ), which constituted respectively $33 \%, 47 \%$ and $20 \%$ of the water bodies. Aquatic vegetation was present in all surveyed water bodies, except one with concrete bottoms and edges.

\subsection{Methods}

\subsubsection{Amphibian inventory and data preparation}

Amphibian species richness in each water body was surveyed in the spring (March - June) period of 2011 and 2012. The presence of amphibians was identified by both visual and auditory surveys using standard methods (for details see Budzik et al. 2013). All observed green frogs were classified as Pelophylax kl. esculentus. The number of individuals of each species present at a site was not counted. Data on previous amphibian distribution in Kraków (at least from the past 20 years) was collected from literature (Guzik et al. 1996) and compared with the currently obtained. Lack of observation of a species with-

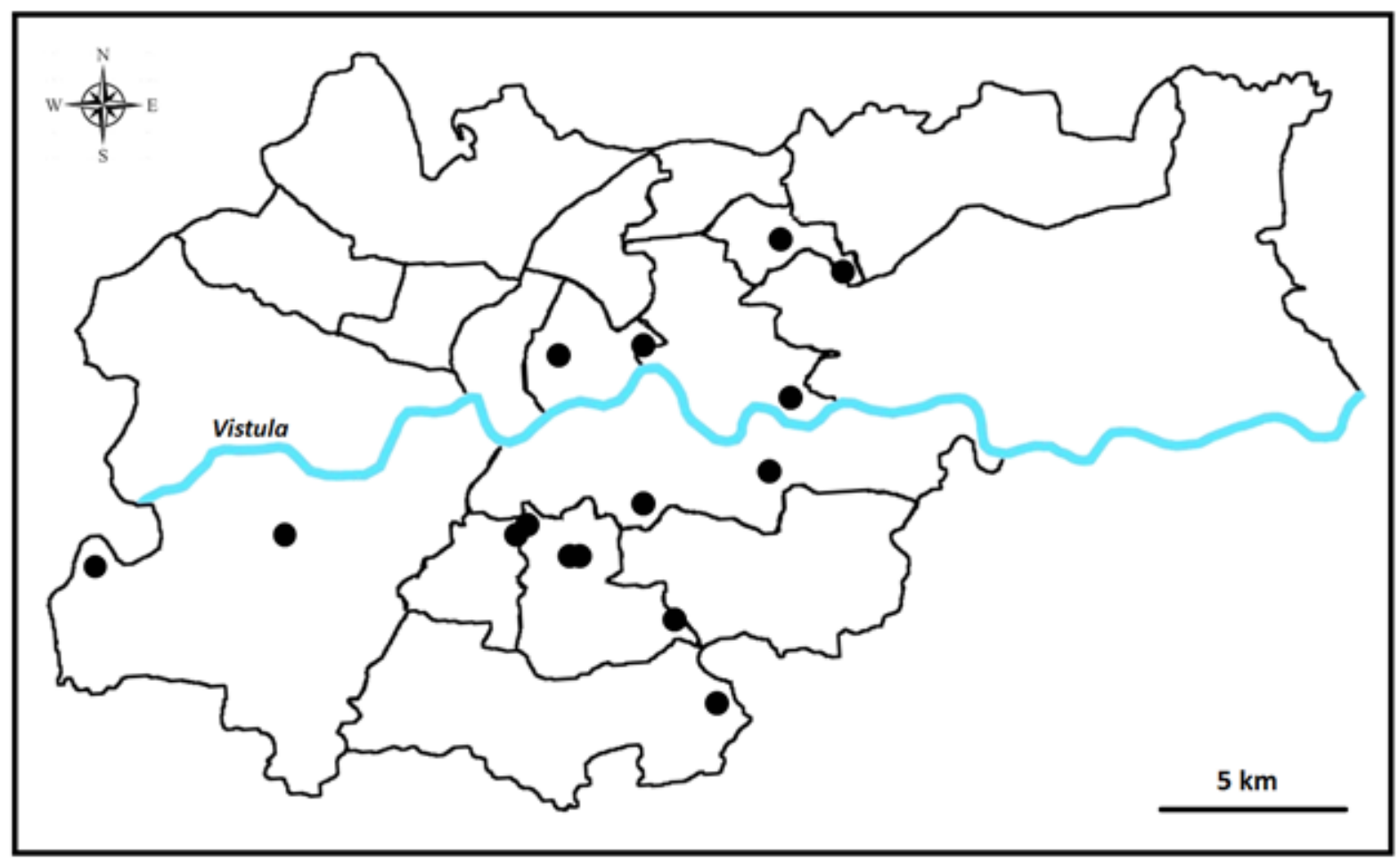

Figure 1. Distribution of 15 investigated water bodies in Kraków city 
in the water body during the current study was defined as local extinction (LE) of the species. Similarly, the observation of non-listed species in the water body was defined as local colonization. The number of LE for each water body was estimated. The water bodies with maximum of two LE were arbitrarily defined as low extinction sites (LES), whereas these with more than two LE were defined as high extinction sites (HES).

\subsubsection{Water sample collection and analysis}

Water samples of each water body were collected during two dry and sunny days in October 2011 (hereinafter referred to autumn) and again in April 2012 (hereinafter referred to spring). The samples were taken from about $0.5 \mathrm{~m}$ from the shore, approximately in the same place in autumn and spring. Each time 0.51 of water samples were placed in plastic 0.51 bottles and transported to the Chemistry Department, Jagiellonian University for analysis. The samples were stored in refrigerators and analyzed for water chemistry variables: calcium $\left(\mathrm{Ca}^{2+}\right)$, magnesium $\left(\mathrm{Mg}^{2+}\right)$, chloride $\left(\mathrm{Cl}^{-}\right)$, ammonium $\left(\mathrm{NH}_{4}^{+}\right)$, nitrate $\left(\mathrm{NO}_{3}^{-}\right)$ and phosphate $\left(\mathrm{PO}_{4}^{3-}\right)$ ion concentration, chemical oxygen demand (COD), $\mathrm{pH}$, total water hardness and conductivity (see Appendix 1 in the supplementary material for details).

\subsubsection{Statistical analysis}

Each water quality indicator was investigated as a variable potentially influencing LE. Using LES and HES as means of each chemical indicator, one-way $t$-test comparing two means was used. In case of $\mathrm{pH}$ indicator, the mean deviations from the $\mathrm{pH}=7$ were calculated. One-way $t$-test was used assuming that LES characterized lower means of indicators than HES. The test was made separately for two seasons (autumn and spring). Spearman's correlation test was used to investigate the association between the number of LE in each water body and the water quality indicator values.

\section{Results}

Currently investigated amphibian species richness ranged from one to four species per water body. The following species of amphibians were observed: great crested newt Triturus cristatus, smooth newt Lissotriton vulgaris, common toad Bufo bufo, fire-bellied toad Bombina bombina, green frogs Pelophylax kl. esculentus, moor frog Rana arvalis and common frog Rana temporaria (Fig. 2, see Appendix 2 in the supplementary material for details). The number of LE ranged from one to five per water body.

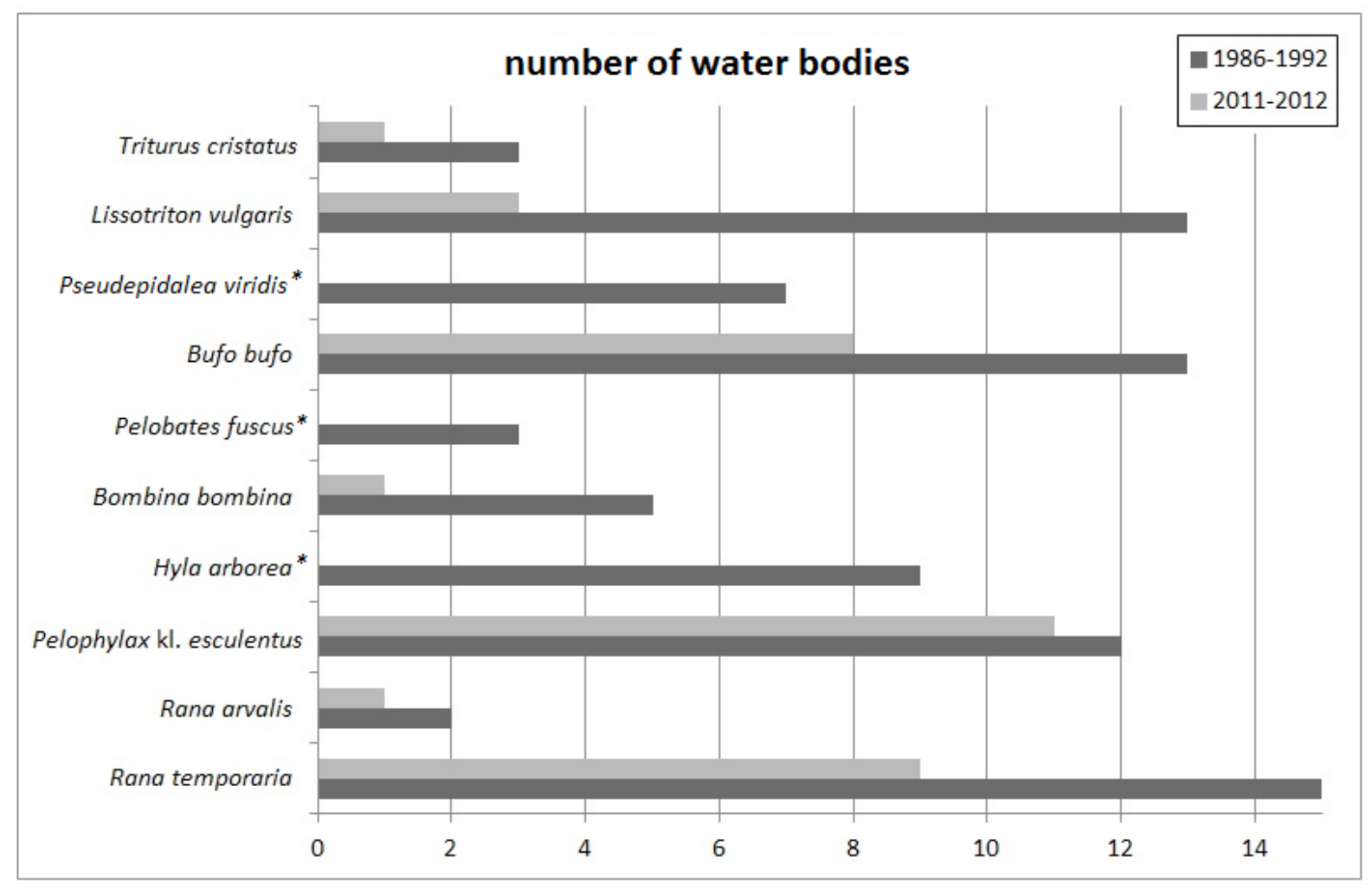

Figure 2. The number of water bodies occupied by the amphibian species in Kraków in the years 1986-1992 (Guzik et al. 1996) and during current study * - not recorded in the present survey 


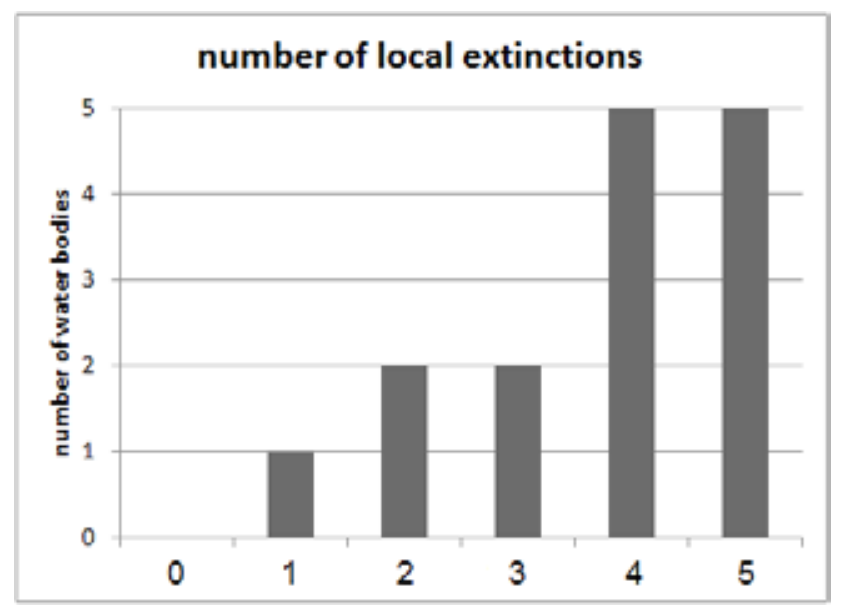

Figure 3. The number of water bodies at determined number of LE.

There were three water bodies defined as LES and the remaining 12 defined as HES (Fig. 3). The mean number of species in LES was 3.7, whereas in HES it was 2.0. Additionally, three colonizations of the green frogs (two in HES) and one colonization of the common toad (in HES) were recorded.

Values of the studied indicators of water quality varied between the seasons (Table 1, see Appendix 3 in the supplementary material for details). LES were characterized by lower average values for most of the studied indicators (except phosphate ion concentration and COD in autumn and COD in spring) (Table 1). Differences between LES

Table 1. Mean values of water quality indicators for LES and HES including the season

\begin{tabular}{|c|c|c|c|c|}
\hline \multirow{2}{*}{ Indicator } & \multicolumn{2}{|c|}{ Autumn } & \multicolumn{2}{c|}{ Spring } \\
\cline { 2 - 5 } & LES & HES & LES & HES \\
\hline $\mathrm{Ca}^{2+}(\mathrm{mg} / \mathrm{l})$ & 60.13 & 128.42 & 52.87 & 121.07 \\
$\mathrm{Mg}^{2+}(\mathrm{mg} / \mathrm{l})$ & 9.37 & 20.41 & 10.63 & 21.78 \\
$\mathrm{Cl}^{-}(\mathrm{mg} / \mathrm{l})$ & 18.73 & 45.51 & 22.43 & 52.14 \\
$\mathrm{NH}_{4}^{+}(\mathrm{mg} / \mathrm{l})$ & 0.21 & 0.27 & 0.26 & 0.29 \\
$\mathrm{NO}_{3}^{-}(\mathrm{mg} / \mathrm{l})$ & 0.79 & 1.34 & 0.44 & 0.85 \\
$\mathrm{PO}_{4}^{3-}(\mathrm{mg} / \mathrm{l})$ & 1.02 & 0.68 & 1.02 & 1.14 \\
$\mathrm{COD}\left(\mathrm{mg} \mathrm{O}_{2} / \mathrm{l}\right)$ & 27.50 & 12.02 & 28.57 & 15.78 \\
$\mathrm{pH}$ & 6.40 & 6.66 & 7.14 & 7.67 \\
$\begin{array}{c}\text { Total water hardness } \\
\left(\mathrm{mg} \mathrm{CaCO}_{3} / \mathrm{l}\right)\end{array}$ & 188.67 & 404.50 & 176.00 & 391.67 \\
Conductivity $(\mu \mathrm{S} / \mathrm{cm})$ & 447.00 & 877.75 & 417.33 & 993.17 \\
\hline
\end{tabular}

and HES were significant for magnesium and chloride ion concentration, regardless of the season. Moreover, in the spring the differences were significant also for nitrate, $\mathrm{pH}$ and conductivity (Table 2). The number of LE was positively correlated ( $r=0.585, N=15, p<0.025)$ with magnesium ion concentration in spring (Table 3 ).

Table 2. T-test comparing two means (LES and HES) of each water quality indicator in autumn and spring

\begin{tabular}{|c|c|c|}
\hline Indicator & Autumn & Spring \\
\hline $\mathrm{Ca}^{2+}$ & $1.272, \mathrm{df}=13, \mathrm{p}<0.11$ & $1.305, \mathrm{df}=13, \mathrm{p}<0.11$ \\
$\mathrm{Mg}^{2+}$ & $1.922, \mathrm{df}=12, \mathrm{p}<0.05$ & $2.582, \mathrm{df}=12, \mathrm{p}<0.025$ \\
$\mathrm{Cl}^{-}$ & $1.789, \mathrm{df}=13, \mathrm{p}<0.05$ & $3.279, \mathrm{df}=11, \mathrm{p}<0.005$ \\
$\mathrm{NH}_{4}^{+}$ & $0.445, \mathrm{df}=13, \mathrm{p}<0.33$ & $0.150, \mathrm{df}=13, \mathrm{p}<0.44$ \\
$\mathrm{NO}_{3}^{-}$ & $0.615, \mathrm{df}=13, \mathrm{p}<0.27$ & $2.030, \mathrm{df}=12, \mathrm{p}<0.05$ \\
$\mathrm{PO}_{4}{ }^{3-}$ & $-0.634, \mathrm{df}=13, \mathrm{p}<0.29$ & $0.173, \mathrm{df}=13, \mathrm{p}<0.43$ \\
$\mathrm{COD}^{-}$ & $-1.524, \mathrm{df}=2, \mathrm{p}<0.13$ & $-1.505, \mathrm{df}=13, \mathrm{p}<0.08$ \\
$\mathrm{pH}$ & $1.232, \mathrm{df}=13, \mathrm{p}<0.12$ & $1.849, \mathrm{df}=13, \mathrm{p}<0.05$ \\
$\begin{array}{c}\text { Total water } \\
\text { hardness }\end{array}$ & $1.396, \mathrm{df}=13, \mathrm{p}<0.09$ & $1.422, \mathrm{df}=13, \mathrm{p}<0.09$ \\
$\begin{array}{c}\text { Conductivity } \\
(\mu \mathrm{S} / \mathrm{cm})\end{array}$ & $1.700, \mathrm{df}=13, \mathrm{p}<0.06$ & $2.643, \mathrm{df}=12, \mathrm{p}<0.025$ \\
\hline
\end{tabular}

Table 3. The $r$ value of the Spearman test investigating correlation between the number of LE in each water body and the water quality indicator values in autumn and spring $(N=15) . * \mathrm{p}<0.025$, the remaining: $\mathrm{p}>0.05$

\begin{tabular}{|c|c|c|}
\hline Indicator & Autumn & Spring \\
\hline $\mathrm{Ca}^{2+}$ & 0.234 & 0.215 \\
$\mathrm{Mg}^{2+}$ & 0.258 & $0.585^{*}$ \\
$\mathrm{Cl}^{-}$ & 0.196 & 0.186 \\
$\mathrm{NH}_{4}^{+}$ & -0.271 & 0.093 \\
$\mathrm{NO}_{3}^{-}$ & -0.207 & 0.150 \\
$\mathrm{PO}_{4}^{3-}$ & -0.076 & -0.059 \\
$\mathrm{COD}^{-}$ & -0.093 & -0.040 \\
$\mathrm{pH}$ & 0.230 & 0.392 \\
Total water hardness & 0.304 & 0.330 \\
Conductivity $(\mu \mathrm{S} / \mathrm{cm})$ & 0.286 & 0.351 \\
\hline
\end{tabular}




\section{Discussion}

This research focused on possible impact of water quality indicators on amphibian extinction. The study area encompassed urban area of Kraków, mostly the central part of the city. In recent years, there were vast urban transformations, which resulted in the loss and isolation of many amphibian habitats (Budzik et al. 2013). The set of 15 water bodies (Fig. 1) was not a random sample, because it was prepared on the basis of data from the previous inventory in the years 1986-1992 (Guzik et al. 1996). Although our sample size is fairly small, it seems to be representative, in terms of historical amphibian species presence (Guzik et al. 1996) and their current state (Kawa et al. 2011; Budzik et al. 2013). Three amphibian species (Hyla arborea, Pelobates fuscus, Pseudepidalea viridis), which were noted by Guzik (1996), were not found in 15 currently investigated water bodies. However, the other research (Kawa et al. 2011; Budzik et al. 2013) showed that the species are still present in some sites in the city. Our present results suggest local extinction of these species and a significant reduction in the number of habitats of B. bombina $(80 \%)$ and $L$. vulgaris (77\%) (Fig. 2). In 80 . and 90 . of the $20^{\text {th }}$ century, LES were known of 5.0 amphibian species on average, whereas HES were known of 5.75 amphibian species. The amphibian richness ranged in that time from four to eight. Assuming, that all water bodies were characterized then by a similar species composition, the condition of their water could also be similar.

Our research revealed that water bodies identified as HES were in majority, which proves the loss of amphibian species and is consistent with the previous studies (Guzik et al. 1996; Kawa et al. 2011; Budzik et al. 2013). As we expected, the values of most chemical indicators were higher in HES than in LES. The most notable difference between LES and HES was for magnesium and chloride ion concentrations and conductivity in spring (Table 2, Table 3). It is connected probably with run-off into the water bodies from the streets. During spring rain showers and snow melting, many chemical compounds can run off into surrounding freshwater systems. Road run-off may include many chemicals such as metals, hydrocarbons and deicing agents (Norrstrom \& Jacks 1998). In recent years, the interest of the latter (deicers) influence on amphibians increased (Sanzo \& Hecnar 2006; Karraker 2007; Karraker \& Ruthig 2009; Harless et al. 2011).

The most common deicing chemicals used on roads are sodium chloride $(\mathrm{NaCl})$, calcium chloride $\left(\mathrm{CaCl}_{2}\right)$ and magnesium chloride $\left(\mathrm{MgCl}_{2}\right)$ (Czerwiński 1978; Sanzo \& Hecnar 2006; Harless et al. 2011). Due to their highly permeable skin and water-dependent life cycle (Stebbins \& Cohen 1995), amphibians are strongly vulnerable to toxicity from these chemicals. High salinity may decrease developmental rate, increase malformations during deve- lopment (Gosner \& Black 1957; Padhye \& Ghate 1992; Gomez-Mestre et al. 2004; Karraker 2007) or increase susceptibility to a lethal water mold (Karraker \& Ruthig 2009). Additionally, some amphibians avoid salt-polluted water bodies and do not demonstrate local adaptation to higher salinities of roadside water bodies (Turtle 2000; Sanzo \& Hecnar 2006; Karraker 2007; Collins \& Russell 2009). Although amphibians may differ in their response to exposure to chemical deicers in run-off, the deicers may influence the demography and community structure of amphibians (Karraker et al. 2008).

Another chemical indicator often associated with deicers is conductivity (Sanzo \& Hecnar 2006; Collins \& Russell 2009). Conductivity is a measure of electrical conductance, which in fresh water is influenced by the presence of ions (Wetzel \& Likens 2000). Water conductivity is important for osmoregulation and amphibian development (Morris \& Tanner 1969; Hovingh 1993), however exposure to increased conductivity greatly varies among the species (Snodgrass et al. 2008). It could negatively affect amphibian water and ion balance (Chambers 2011), their behavior (Haramura 2007; Karraker et al. 2008), development (Snodgrass et al. 2008) and even survival (Sanzo \& Hecnar 2006).

In addition to habitat loss and fragmentation (Stuart et al. 2004), water quality appears to be an important factor which may limit the occurrence of amphibians. Among amphibians, the most vulnerable to water pollution may be rare species like B. bombina and $L$. vulgaris and considered to be locally extinct like $H$. arborea, $P$. fuscus, $P$. viridis. However, $P$. kl. esculentus, B. bufo and $R$. temporaria are still present in many water bodies. These latter species colonize heterogeneous habitats (Pavignano et al. 1990) and seem to be more resistant to adverse changes in their aquatic environment. Because of the proximity of roads, HES may possess increased concentration of chemicals, which may in turn affect amphibian populations, leading even to the extinction of some species. This seems to be confirmed by the fact that none of the LES were situated in the immediate vicinity of a road. Moreover, roads constitute barriers for amphibians and can also lead to the high mortality or even local extinction of these highly vulnerable vertebrates. Furthermore, there are many other environmental factors, that have not been investigated here, and which may have also influenced the studied LE of amphibians.

\section{Conclusions}

Historical data and the current study together indicate a decrease in amphibian species presence in Kraków urban environment. Our results support the hypothesis that chemical contamination is a factor leading to amphibian decline (Blaustein et al. 1994; Hayes et al. 2002). We show 
that LES and HES differ in terms of chemical indicators considered to be harmful to amphibians. Considering the above threats, it is crucial to provide adequate protection of water bodies. The knowledge of the relationship between amphibian richness and water quality may allow to better identify habitat components for protection and new habitat planning.

\section{Acknowledgements}

We would like to thank Dominik Budzik and Grzegorz Kawa for help in water samples collection, and three anonymous reviewers for providing comments that greatly improved previous versions of this manuscript.

\section{References}

Andrews K. M. \& Gibbons J. W., 2005, How do highways influence snake movement? Behavioral responses to roads and vehicles, Copeia 4: 772-782.

Baker J. \& Waights V., 1993, The effect of sodium nitrate on the growth and survival of toad tadpoles (Bufo bufo) in the laboratory, Herpetological Journal 3: 147-148.

Blaustein A. R., Wake D. B. \& Sousa W. P., 1994, Amphibian declines: judging, stability, persistence, and susceptibility of populations to local and global extinctions, Conservation Biology 8: 60-71.

Budzik K. A., Budzik K. M. \& Żuwała K., 2013, Amphibian situation in urban environment - history of the common toad Bufo bufo in Kraków (Poland), Ecological Questions 18: 75-79.

Chambers D. L., 2011, Increased conductivity affects corticosterine levels and prey comsumption in larval amphibians, Journal of Herpetology 45(2): 219-223.

Collins S. J. \& Russell R. W., 2009, Toxicity of road salt to Nova Scotia amphibians, Environmental Pollution 157: 320-324.

Czerwiński Z., 1978, Wpływ chemicznej technologii odśnieżania ulic na gleby i roślinność drzewiastą aglomeracji miejskich [The influence of chemical technology of streets cleaning on soil and woody vegetation of urban agglomerations], Zeszyty Naukowe SGGW, Warszawa, Rozprawa Naukowa [Scientific Thesis] 104: 5-39.

Gibbs J. P., 1998, Amphibian movements in response to forest edges, roads, and streambeds in southern New England, Journal of Wildlife Management 62: 584-589.

Gosner K. L. \& Black I. H., 1957, The effects of acidity on the development and hatching of New Jersey frogs, Ecology 38:b256-262.

Gomez-Mestre I., Tejedo M., Ramayo E. \& Estepa J., 2004, Developmental alterations and osmoregulatory physiology of a larval anuran under osmotic stress, Physiological and Biochemical Zoology 77: 267-274.

Guzik M., Schimscheiner L., Zakrzewski M., Zamachowski W. \& Zyśk A., 1996, Herpetofauna miasta Krakowa [Herpetofauna of Kraków city], Studia Ośrodka Dokumentacji Fizjograficznej PAN, Kraków 24: 247-262.

Haramura T., 2007, Microhabitat selection by tadpoles of Buergeria japonica inhabiting the coastal area, Journal of Ethology 25: 3-7.

Harles M. L., Huckins C. J., Grant J. B. \& Pypker T. G., 2011, Effects of six chemical deicers on larval wood frogs (Rana sylvatica), Environmental Toxicology and Chemistry 30(7): 1637-1641.

Hayes T. B., Collins A., Lee M., Magdelena M., Noriega N., Stuart A. A. \& Vonk A., 2002, Hermaphroditic, demasculinized frogs after exposure to the herbicide atrazine at low ecologically relevant doses, Proceedings of the National Academy of Sciences USA 99: 5476-5480.

Hof C., Araujo M. B., Jetz W. \& Rahbek C., 2011, Additive threats from pathogens, climate and landuse change for global amphibian diversity, Nature 480: 516-519.

Hovingh P., 1993, Aquatic habitats, life history observations, and zoogeographic considerations of the spotted frog (Rana pretiosa) in Tule Valley, Utah, Great Basin Naturalist 53: 168-179.

Karraker N. E., 2007, Are embryonic and larval green frogs (Rana clamitans) insensitive to road deicing salt?, Herpetological Conservation and Biology 2: 35-41.

Karraker N. E., Gibbs J. P. \& Vonesh J. R., 2008, Impacts of road de-icing salt on the demography of vernal pool-breeding amphibians, Ecological Applications 18: 724-734.

Karraker N. E. \& Ruthig G. R., 2009, Effect of road deicing salt on the susceptibility of amphibian embryos to infection by water molds, Environmental Research 109: 40-45.

Kawa K., Budzik K., Żuwała K. \& Bury S., 2011, The amphibian species composition of selected Cracow water bodies over the last decades, [in:] P. Indykiewicz, L. Jerzak, J. Böhner, B. Kavanagh (eds.) Urban Fauna, Studies of animals biology, ecology and conservation in European cities, Uniwersytet Technologiczno-Przyrodniczy w Bydgoszczy [University of Technology and Life Sciences in Bydgoszcz], Bydgoszcz: 345-352.

Klaver R. W., Peterson C. R. \& Patla D. A., 2013, Influence of water conductivity on amphibian occupancy in the Greater Yellowstone Ecosystem, Western North American Naturalist 73(2): 184-197.

Loman J. \& Lardner B., 2006, Does pond quality limit frogs Rana arvalis and Rana temporaria in agricultural landscapes? A field experiment, Journal of Applied Ecology 43: 690-700. 
Morris R. L. \& Tanner W. W., 1969, The ecology of the Western spotted frog, Rana pretiosa Baird and Girard, a life history study, Great Basin Naturalist 24: 45-81.

Norrstrom A. C. \& Jacks G.,1998, Concentration and fractionation of heavy metals in roadside soils receiving de-icing salts, The Science of the Total Environment 218: 161-174.

Padhye A. D. \& Ghate H. V., 1992, Sodium chloride and potassium chloride tolerance of different stages of the frog, Microhyla ornata, Herpetological Journal 2: 1823.

Pavignano I., Giacoma C. \& Castellano S., 1990, A multivariate analysis of amphibian habitat determinants in north-western Italy, Amphibia-Reptila 11: 311-324.

Reh W. \& Seitz A., 1990, The influence of land use on the genetic structure of populations of the common frog Rana temporaria, Biological Conservation 54: 239249.

Sanzo D. \& Hecnar S. J., 2006, Effects of road de-icing salt $(\mathrm{NaCl})$ on larval wood frogs (Rana sylvatica), Environmental Pollution 140: 247-256.

Skei J. K. \& Dolmen D., 2006, Effects of pH, aluminium, and soft water on larvae of the amphibians Bufo bufo and Triturus vulgaris, Canadian Journal of Zoology 84: 1668-1677.
Snodgrass J. W., Casey R. E., Joseph D. \& Simon J. A., 2008, Microcosm investigations of stormwater pond sediment toxicity to embryonic and larval amphibians: variation in sensitivity among species, Environmental Pollution 154: 291-297.

St. Clair C. C., 2003, Comparative permeability of roads, rivers, and meadows to songbirds of Banff National Park, Conservation Biology 17: 1151-1160.

Stebbins R. C. \& Cohen N., 1995, Natural history of amphibians, Princeton University Press, Princeton.

Stuart S. N., Chanson J. S., Cox N. A., Young B. E., Rodrigues A. S. L., Fischman D. L. \& Waller R. W., 2004, Status and trends of amphibian declines and extinctions worldwide, Science 306: 1783-1786.

Turtle S. L., 2000, Embryonic survivorship of the spotted salamander (Ambystoma maculatum) in roadside and woodland vernal ponds in southeastern New Hampshire, Journal of Herpetology 34: 60-67.

Vitt L. J., Caldwell J. P., Wilbur H. M. \& Smith D. C., 1990, Amphibians as harbingers of decay, BioScience 40: 418.

Wetzel R. G. \& Likens G. E., 2000, Limnological Analyses, 3rd ed., Springer-Verlag, New York.

Appendix 1

\begin{tabular}{|c|c|}
\hline Indicator & Method used \\
\hline $\mathrm{Ca}^{2+}$ & $\begin{array}{l}\text { EDTA titration method was used. } 0.0031 \text { of } 30 \% \text { sodium hydroxide and a pinch of kalces reagent to } 0.051 \text { of the water } \\
\text { sample was added. The solution was titrated with } 0.01 \mathrm{~mol} / \mathrm{l} \text { EDTA, until the coloration changed from red to blue. }\end{array}$ \\
\hline $\mathrm{Mg}^{2+}$ & It was calculated as the difference between the received values for total water hardness and $\mathrm{Ca}^{2+}$ ion concentration. \\
\hline $\mathrm{Cl}^{-}$ & $\begin{array}{l}\text { The argentometric Mohr method was used. } 0.001 \mathrm{lof}_{2} \mathrm{CrO}_{4} \text { to } 0.051 \text { of water sample was given. The solution was } \\
\text { titrated with silver nitrate }\left(\mathrm{AgNO}_{3}\right) \text { until a yellow-brown coloration in the solution became visible. }\end{array}$ \\
\hline $\mathrm{NH}_{4}^{+}$ & The Spectroquant no. 14752 (Merck) test according to the supplier's instructions was used. \\
\hline $\mathrm{NO}_{3}^{-}$ & $\begin{array}{l}\text { It was measured spectrophotometrically in the presence of sodium salicylate in a sulfuric acid (VI) environment. } \\
\text { To } 0.021 \text { of each water sample } 3 \text { drops of } 0.5 \% \mathrm{NaOH} \text { and } 0.0011 \text { of sodium salicylate were given. The solutions } \\
\text { were then evaporated until dry in a water bath and } 0.0011 \text { of sulfuric acid was given to each of the samples. After } \\
10 \text { minutes, } 0.021 \text { of distilled water and } 0.0071 \text { of potassium-sodium tartrate was added. The solutions were placed } \\
\text { in } 0.051 \text { flasks and their absorbance measured at } 410 \mathrm{~nm} \text { on a Pharo } 300 \text { Spectrophotometer. }\end{array}$ \\
\hline $\mathrm{PO}_{4}^{3-}$ & It was measured with the Spectroquant no. 14848 test (Merck) according to the supplier's instructions. \\
\hline COD & $\begin{array}{l}\text { It was measured as COD-Mn. Depending on the size of the polluting substances, either } 0.01,0.025,0.05,0.75 \text { or } \\
0.11 \text { of water was taken, placed in flasks and filled, when necessary, with distilled water to reach the total volume } \\
\text { of } 0.11 \text {. To each flask } 0.011 \text { of sulfuric acid and } 0.011 \text { of potassium permanganate was added and the flasks were } \\
\text { heated up for } 30 \text { minutes. Immediately afterwards, } 0.011 \text { of sodium oxalate was added and the solutions were mixed. } \\
\text { The solutions was titrated with potassium permanganate until a light pink colouration became visible. }\end{array}$ \\
\hline $\mathrm{pH}$ & $\begin{array}{l}\text { It was measured by a combined electrode with an Elmetron } \mathrm{CP}-401 \mathrm{pH}-\text { meter. The } \mathrm{pH} \text {-meter was calibrated using } \\
\text { a buffer solution with the known } \mathrm{pH} \text { of } 7 \text {. }\end{array}$ \\
\hline $\begin{array}{l}\text { Total water } \\
\text { hardness }\end{array}$ & $\begin{array}{l}\text { EDTA titration method was used. To } 0.051 \text { of the tested water, } 0.0051 \text { of ammonium buffer }(\mathrm{pH}=10) \text { and a pinch of } \\
\text { ErioT was added. The solution was mixed and titrated with } 0,01 \mathrm{~mol} / \mathrm{l} \text { EDTA, until the change of colouration from } \\
\text { violet-pink to blue was observed. }\end{array}$ \\
\hline$y$ & It was measured using the inoLab Cond 7110 conductometer calibrated with a $0.1 \mathrm{~mol} / 1 \mathrm{KCl}$ solution. \\
\hline
\end{tabular}


Appendix 2

\begin{tabular}{|c|c|c|c|c|c|c|c|c|c|c|}
\hline $\begin{array}{l}\text { Geographical } \\
\text { coordinates }\end{array}$ & 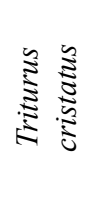 & 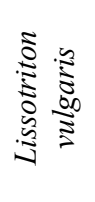 & 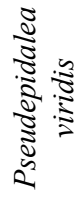 & $\begin{array}{l}0 \\
\frac{3}{3} \\
0 \\
0\end{array}$ & 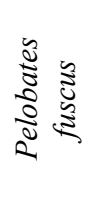 & 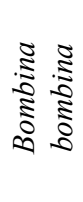 & 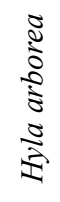 & 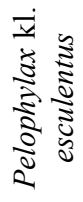 & 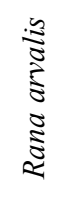 & 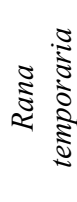 \\
\hline $57.3888^{\circ} \mathrm{N} \quad 24.7209^{\circ} \mathrm{E}$ & $+/-$ & $+/-$ & $-/-$ & $+/+$ & $-/-$ & $-/-$ & $+/-$ & $+/+$ & $-/-$ & $+/+$ \\
\hline $57.2235^{\circ} \mathrm{N} 23.6314^{\circ} \mathrm{E}$ & $-/-$ & $+/-$ & $-/-$ & $-/+$ & $-/-$ & $+/-$ & $+/-$ & $-/+$ & $-/-$ & $+/+$ \\
\hline $57.3753^{\circ} \mathrm{N} \quad 24.3353^{\circ} \mathrm{E}$ & $-/-$ & $+/-$ & $-/-$ & $+/+$ & $-/-$ & $-/-$ & $+/-$ & $+/+$ & $-/-$ & $+/+$ \\
\hline $56.2107^{\circ} \mathrm{N} \quad 24.0149^{\circ} \mathrm{E}$ & $-/-$ & $+/+$ & $-/-$ & $+/+$ & $-/-$ & $+/+$ & $-/-$ & $+/+$ & $-/-$ & $+/+$ \\
\hline $55.7899^{\circ} \mathrm{N} \quad 23.9286^{\circ} \mathrm{E}$ & $-/-$ & $-/-$ & $-/-$ & $+/-$ & $-/-$ & $-/-$ & $+/-$ & $+/+$ & $+/-$ & $+/-$ \\
\hline $56.8477^{\circ} \mathrm{N} \quad 24.4349^{\circ} \mathrm{E}$ & $-/-$ & $+/+$ & $+/-$ & $+/+$ & $-/-$ & $-/-$ & $+/-$ & $-/+$ & $-/-$ & $+/+$ \\
\hline $57.0624^{\circ} \mathrm{N} \quad 24.4665^{\circ} \mathrm{E}$ & $+/-$ & $+/-$ & $+/-$ & $+/+$ & $-/-$ & $-/-$ & $+/-$ & $-/+$ & $+/+$ & $+/+$ \\
\hline $57.0571^{\circ} \mathrm{N} \quad 24.1301^{\circ} \mathrm{E}$ & $-/-$ & $+/-$ & $-/-$ & $+/-$ & $-/-$ & $+/-$ & $+/-$ & $+/+$ & $-/-$ & $+/-$ \\
\hline $57.3676^{\circ} \mathrm{N} \quad 24.1810^{\circ} \mathrm{E}$ & $-/-$ & $-/-$ & $+/-$ & $+/-$ & $-/-$ & $-/-$ & $-/-$ & $+/+$ & $-/-$ & $+/-$ \\
\hline $57.5218^{\circ} \mathrm{N} \quad 24.6216^{\circ} \mathrm{E}$ & $-/-$ & $+/-$ & $+/-$ & $+/+$ & $-/-$ & $-/-$ & $-/-$ & $+/-$ & $-/-$ & $+/-$ \\
\hline $56.7930^{\circ} \mathrm{N} \quad 24.0309^{\circ} \mathrm{E}$ & $-/-$ & $+/-$ & $+/-$ & $+/-$ & $-/-$ & $+/-$ & $-/-$ & $+/+$ & $-/-$ & $+/-$ \\
\hline $56.7889^{\circ} \mathrm{N} \quad 24.0404^{\circ} \mathrm{E}$ & $-/-$ & $+/-$ & $+/-$ & $+/-$ & $-/-$ & $+/-$ & $-/-$ & $+/+$ & $-/-$ & $+/-$ \\
\hline $56.9086^{\circ} \mathrm{N} \quad 23.9734^{\circ} \mathrm{E}$ & $-/-$ & $+/-$ & $-/-$ & $+/+$ & $+/-$ & $-/-$ & $+/-$ & $+/-$ & $-/-$ & $+/+$ \\
\hline $56.9148^{\circ} \mathrm{N} \quad 23.9831^{\circ} \mathrm{E}$ & $-/-$ & $+/-$ & $-/-$ & $+/+$ & $+/-$ & $-/-$ & $+/-$ & $+/-$ & $-/-$ & $+/+$ \\
\hline $57.1357^{\circ} \mathrm{N} \quad 23.8250^{\circ} \mathrm{E}$ & $+/+$ & $+/+$ & $+/-$ & $+/-$ & $+/-$ & $+/-$ & $-/-$ & $+/+$ & $-/-$ & $+/+$ \\
\hline
\end{tabular}

data by Guzik et al. 1996 / present data

+ presence of the species

- absence of the species 
Appendix 3

\begin{tabular}{|c|c|c|c|c|c|c|c|c|c|c|c|}
\hline Geographical coordinates & Season & $\mathrm{pH}$ & $\begin{array}{c}\text { Conductivity } \\
\mu \mathrm{S} / \mathrm{cm}\end{array}$ & $\begin{array}{c}\mathrm{Cl}^{-} \\
\mathrm{mg} / 1\end{array}$ & $\begin{array}{l}\mathrm{Ca}^{2+} \\
\mathrm{mg} / \mathrm{l}\end{array}$ & $\begin{array}{l}\mathrm{Mg}^{2+} \\
\mathrm{mg} / 1\end{array}$ & $\begin{array}{l}\text { Total water } \\
\text { hardness } \\
\mathrm{mgCaCO}_{3} / 1\end{array}$ & $\begin{array}{c}\mathrm{COD} \\
\mathrm{mgO}_{2} / 1\end{array}$ & $\begin{array}{c}\mathrm{NH}_{4}^{+} \\
\mathrm{mg} / \mathrm{l}\end{array}$ & $\begin{array}{l}\mathrm{NO}_{3}^{-} \\
\mathrm{mg} / 1\end{array}$ & $\begin{array}{l}\mathrm{PO}_{4}^{3-} \\
\mathrm{mg} / 1\end{array}$ \\
\hline \multirow{2}{*}{$57.3888^{\circ} \mathrm{N} \quad 24.7209^{\circ} \mathrm{E}$} & a & 6.54 & 556 & 24.8 & 76.1 & 6.3 & 216.0 & 9.6 & 0.265 & 3.38 & 0.15 \\
\hline & $\mathrm{s}$ & 8.15 & 437 & 23.8 & 75.0 & 6.2 & 210.0 & 8.98 & 0.386 & 2.71 & 0.40 \\
\hline \multirow{2}{*}{$57.2235^{\circ} \mathrm{N} \quad 23.6314^{\circ} \mathrm{E}$} & a & 6.15 & 695 & 63.1 & 65.0 & 25.7 & 268.0 & 5.1 & 0.299 & 3.95 & 0.42 \\
\hline & $\mathrm{s}$ & 7.61 & 516 & 24.8 & 54.5 & 5.3 & 158.0 & 8.4 & 0.302 & 0.50 & 0.50 \\
\hline \multirow{2}{*}{$57.3753^{\circ} \mathrm{N} \quad 24.3353^{\circ} \mathrm{E}$} & a & 6.15 & 608 & 27.6 & 84.2 & 13.6 & 266.0 & 39.7 & 0.303 & 1.34 & 2.21 \\
\hline & $\mathrm{s}$ & 7.33 & 577 & 25.5 & 83.4 & 11.1 & 254.0 & 37.3 & 0.699 & 0.57 & 2.02 \\
\hline \multirow{2}{*}{$56.2107^{\circ} \mathrm{N} \quad 24.0149^{\circ} \mathrm{E}$} & $\mathrm{a}$ & 6.58 & 340 & 8.1 & 39.3 & 6.8 & 126.0 & 35.1 & 0.228 & 0.19 & 0.23 \\
\hline & $\mathrm{s}$ & 7.12 & 359 & 20.5 & 34.4 & 13.1 & 140.0 & 31.9 & 0.064 & 0.437 & 0.84 \\
\hline \multirow{2}{*}{$55.7899^{\circ} \mathrm{N} \quad 23.9286^{\circ} \mathrm{E}$} & a & 6.40 & 820 & 36.9 & 124.2 & 6.3 & 336.0 & 16.3 & 0.037 & 0.946 & 0.24 \\
\hline & $\mathrm{s}$ & 7.47 & 1016 & 56.0 & 138.7 & 18.9 & 424.0 & 18.0 & 0.084 & 0.490 & 3.91 \\
\hline \multirow{2}{*}{$56.8477^{\circ} \mathrm{N} \quad 24.4349^{\circ} \mathrm{E}$} & a & 6.48 & 393 & 20.5 & 56.9 & 7.7 & 174.0 & 7.7 & 0.102 & 0.845 & 0.63 \\
\hline & $\mathrm{s}$ & 6.98 & 316 & 21.3 & 40.8 & 7.7 & 134.0 & 16.5 & 0.030 & 0.317 & 0.20 \\
\hline \multirow{2}{*}{$57.0624^{\circ} \mathrm{N} \quad 24.4665^{\circ} \mathrm{E}$} & a & 6.93 & 1126 & 90.7 & 153.1 & 4.8 & 402.0 & 9.9 & 0.092 & 0.46 & 0.56 \\
\hline & $\mathrm{s}$ & 7.68 & 1290 & 115.6 & 175.5 & 23.8 & 536.0 & 9.0 & 0.708 & 0.60 & 0.86 \\
\hline \multirow{2}{*}{$57.0571^{\circ} \mathrm{N} \quad 24.1301^{\circ} \mathrm{E}$} & $\mathrm{a}$ & 6.96 & 725 & 50.3 & 78.5 & 18.5 & 272.0 & 7.5 & 0.201 & 0.42 & 0.40 \\
\hline & $\mathrm{s}$ & 8.14 & 756 & 51.8 & 68.1 & 27.2 & 284.0 & 14.5 & 0.27 & 1.05 & 0.14 \\
\hline \multirow{2}{*}{$57.3676^{\circ} \mathrm{N} \quad 24.1810^{\circ} \mathrm{E}$} & a & 6.31 & 446 & 16.3 & 60.1 & 15.1 & 212.0 & 16.1 & 0.024 & 0.63 & 0.35 \\
\hline & $\mathrm{s}$ & 7.56 & 455 & 17.7 & 55.3 & 13.1 & 192.0 & 33.4 & 0.118 & 0.45 & 0.41 \\
\hline \multirow{2}{*}{$57.5218^{\circ} \mathrm{N} \quad 24.6216^{\circ} \mathrm{E}$} & a & 7.10 & 463 & 24.8 & 68.1 & 4.4 & 188.0 & 7.9 & 0.239 & 3.95 & 0.16 \\
\hline & $\mathrm{s}$ & 7.40 & 649 & 78.0 & 65.7 & 17.5 & 236.0 & 7.5 & 0.074 & 0.54 & 0.15 \\
\hline \multirow{2}{*}{$56.7930^{\circ} \mathrm{N} \quad 24.0309^{\circ} \mathrm{E}$} & a & 6.90 & 1084 & 28.7 & 129.8 & 65.6 & 594.0 & 8.7 & 0.078 & 0.415 & 0.05 \\
\hline & $\mathrm{s}$ & 7.96 & 1102 & 29.8 & 125.8 & 37.4 & 468.0 & 8.0 & 0.109 & 0.38 & 1.64 \\
\hline \multirow{2}{*}{$56.7889^{\circ} \mathrm{N} \quad 24.0404^{\circ} \mathrm{E}$} & a & 6.87 & 1472 & 80.5 & 173.1 & 42.3 & 606.0 & 11.1 & 0.576 & 0.885 & 0.67 \\
\hline & $\mathrm{s}$ & 8.19 & 1561 & 88.6 & 170.7 & 53.0 & 644.0 & 12.2 & 0.066 & 0.51 & 0.36 \\
\hline \multirow{2}{*}{$56.9086^{\circ} \mathrm{N} \quad 23.9734^{\circ} \mathrm{E}$} & a & 7.03 & 1521 & 54.2 & 325.4 & 25.3 & 916.0 & 9.5 & $>0.64$ & 0.275 & 2.59 \\
\hline & $\mathrm{s}$ & 7.42 & 2810 & 53.8 & 339.1 & 30.6 & 972.0 & 8.4 & $>0.64$ & 1.35 & 2.43 \\
\hline \multirow{2}{*}{$56.9148^{\circ} \mathrm{N} \quad 23.9831^{\circ} \mathrm{E}$} & $\mathrm{a}$ & 6.42 & 1342 & 59.5 & 265.3 & 25.3 & 766.0 & 12.9 & $>0.64$ & 0.175 & 1.99 \\
\hline & $\mathrm{s}$ & 8.02 & 1143 & 66.0 & 170.0 & 20.0 & 506.0 & 9.0 & 0.105 & 0.66 & 1.16 \\
\hline \multirow{2}{*}{$57.1357^{\circ} \mathrm{N} \quad 23.8250^{\circ} \mathrm{E}$} & $\mathrm{a}$ & 6.30 & 283 & 16.3 & 22.4 & 5.3 & 78.0 & 29.6 & 0.174 & 0.604 & 0.61 \\
\hline & $\mathrm{s}$ & 6.49 & 183 & 19.8 & 14.4 & 8.3 & 70.0 & 52.0 & 0.616 & 0.98 & 1.76 \\
\hline
\end{tabular}

a-autumn

$\mathrm{s}$ - spring 